\title{
TINJAUAN YURIDIS TERHADAP HILANGNYA HAK GUNA BANGUNAN KARENA DI TELANTARKAN OLEH PEMILIKNYA DITINJAU PERATURAN KEPALA BADAN PERTANAHAN NASIONAL REPUBLIK INDONESIANOMOR 4 TAHUN 2010 TENTANG TATA CARA PENERTIBAN TANAH TERLANTAR
}

\author{
Eko Adrianto ${ }^{1)}$, Indra Perdana ${ }^{2)}$ \\ ${ }^{1)}$ Fakultas Hukum Universitas Asahan \\ ${ }^{2)}$ Fakultas Hukum Universitas Asahan \\ email: ekoadrianto1978@gmail.com ${ }^{1}$ indrap55@gmail.com ${ }^{2)}$
}

\begin{abstract}
ABSTRAK
Hak Guna bangunan ialah suatu keberadaan hak yang dimiliki oleh subyek hukum, yang mana di dasari pada ketentuan yang diatur di dalam UUPA. Mengenai Hak Guna Bangunan, maka yang dalam hal ini diberikan suatu hak atas tanah ialah dengan tujuan agar dapat membangun suatu permukiman berupa rumah ataupun juga dalam hal ini dapat berbentuk seperti kantor. Tanah ialah suatu daratan yang terbentuk dikarenakan adanya suatu pristiwa alam, yang dimana dapat dimanfaatkan sebagai lahan usaha pertanian, peternakan, dan perikanan serta sebagai salah satu tempat untuk mendirikan bangunan temapt tinggal/menjalankan usaha. Pada penelitian hukum ini menggunakan tipe penelitian hukum normatif. Bahan hukum primer, yaitu : Peraturan PerundangUndangan. Bahan hukum sekunder, yaitu : buku-buku hukum. Bahan hukum tersier, yaitu : buku-buku non hukum. Pemberian Hak Guna Bangunan di atas tanah negara dan tanah Hak Pengelolaan, dalam Undang-Undang Pokok Agraria tidak jauh berbeda dari pemberian Hak Numpang Karang (recht van postal) yang diatur dalam Pasal 711 jo. Pasal 713 Kitab Undang-Undang Hukum Perdata.
\end{abstract}

Kata Kunci : Hak Guna Bangunan, Tanah Terlantar, Tinjauan Yuridis.

\begin{abstract}
Building use rights are the existence of rights owned by legal subjects, which are based on the provisions stipulated in the UUPA. Regarding Building Use Rights, in this case a right to land is granted with the aim of being able to build a settlement in the form of a house or in this case it can be shaped like an office. Land is a land that is formed due to natural events, which can be used as agricultural, livestock and fishery business land and as a place to build a building where you live / run a business. In this legal research using normative legal research type. Primary legal materials, namely: Prevailing Laws. Secondary legal materials, namely: law books. Tertiary legal materials, namely: non-legal books. The granting of Building Use Rights on state land and Management Rights land, in the Basic Agrarian Law is not much different from the granting of Numpang Karang Rights (recht van postal) as stipulated in Article 711 jo. Article 713 of the Civil Code.
\end{abstract}

Keywords: Building Use Rights, Abandoned Land, Juridical Overview. 


\section{CITRA JUSTICIA}

\section{Volume 22 No. 1, FEBRUARI 2021 ISSN 2686-5750 (ONLINE) \\ ISSN 1411-0717 (CETAK)}

\section{PENDAHULUAN}

Setiap orang memerlukan kebutuhan hidup yang berbeda-beda, sehingga harus memiliki penghasilan agar dapat memenuhi dan membiayai semua kebutuhan hidup tersebut. Negara juga tidak jauh berbeda dengan keadaan di atas, karena negara juga memiliki kebutuhan serta membutuhkan biaya pembangunan semua sarana dan prasarana untuk kepentingan warga masyarakatnya. Sebagai upaya untuk memenuhi kebutuhan tersebut, negara melalui pemerintah sebagai penyelenggara pemerintahan memperoleh kebutuhan tersebut ada yang berasal dari dalam negeri dan ada yang dari luar negeri. (Bahmid, 2016). ${ }^{1}$

Hak Guna bangunan ialah suatu keberadaan hak yang dimiliki oleh subyek hukum, yang mana di dasari pada ketentuan yang diatur di dalam UUPA. Mengenai Hak Guna Bangunan, maka yang dalam hal ini diberikan suatu hak atas tanah ialah dengan tujuan agar dapat membangun suatu permukiman berupa rumah ataupun juga dalam hal ini dapat berbentuk seperti kantor.

Tanah ialah suatu daratan yang terbentuk dikarenakan adanya suatu pristiwa alam, yang dimana dapat dimanfaatkan sebagai lahan usaha pertanian, peternakan, dan perikanan serta sebagai salah satu

\footnotetext{
Bahmid, Penetapan Bea Perolehan Hak Atas Tanah Dan Bangunan Dalam Peralihan Hak Atas Tanah Di Kabupaten Asahan (Tinjauan Yuridis Peraturan Daerah Kabupaten Asahan Nomor 3 Tahun 2011 Tentang Bea Perolehan Hak Atas Tanah Dan Bangunan), (Kisaran : Fakultas Hukum, Universitas Asahan, 2016), hlm. 1.
}

tempat untuk mendirikan bangunan tempat tinggal/menjalankan usaha. (Togie Halomoan Gultom, Bahmid, Irda Pratiwi, 2019). ${ }^{2}$

Dalam hal ini menurut ketentuan yang diatur di dalam UUD Tahun 1945, yang dalam hal ini menyatakan bahwasannya bumi, air, dan ruang angkas dikuasai oleh negara dan sebesar-besarnya dapat digunakan oleh masyarakat untuk kemakmuran rakyat.

Adapun di dalam konstitusi yang ada di Indonesia, maka negara yang sebagai pemilik serta sekaligus penguasa atas segala teritorial terhadap batas-batas negara di Indonesia, maka pertanahan yang ada di Indonesia diberi suatu penjaminan agar masyarakat di Indonesia dapat mengelola tanah.

Mengenai suatu pengelolaan terhadap tanah yang ada di Indonesia, maka kepemilikan tanah yang dimiliki oleh masyarakat pribadi haruslah didasari pada suatu bukti autentik yang diakui oleh negara sesuai dengan ketentuan yang tertuang di dalam UUPA.

Namun dalam hal ini terkadang tanah juga hampir kerap terjadi suatu permasalahan, dimana terkadang tanah yang dimiliki bisa saja terjadi bertambah dikarenakan oleh faktor/pristiwa alam yang terjadi.

Bertambahnya atas kepemilikan terhadap tanah merupakan suatu kemungkinan yang dimana dapat berdampak secara

2 Togie Halomoan Gultom, Bahmid, Irda Pratiwi, Peran Lurah Dalam Ganti Rugi Tanah Dikelurahan Keramat Kubah Kota Tanjungbalai, (Kisaran : Fakultas Hukum, Universitas Asahan, 2019), hlm. 45 
positif dan secara negatif. Adapun dampak secara positif terhadap tanah yang dimiliki ialah pemilik tanah memiliki keuntungan tersendiri, karena tanah yang dimilikinya bertambah yang mana dikarenakan adanya proses gejala alam, seperti lumpur yang terletak di kawasan tanah yang dimiliki dan termasuk ke dalam pertepian sungai atau tepi laut yang berlumpur, maka hal ini dapat terjadi apabila sungai tersebut mengering, sehingga sungai tersebut menjadi tanah/lahan yang luas, sehingga tanah yang dimiliki orang yang berdekatan dengan daerah pinggir sungai, maka mendaptkan keuntungan tersendiri.

Tanah adalah merupakan salah satu unsur yang paling utama di dalam suatu wilayah, sebab bahwasannya di dalam suatu wilayah seperti Indonesia yang merupakan sebagai negara yang agraris, dalam hal ini menyatakan bahwasannya tanah memiliki kedudukan yang sangat penting di dalam melakukan suatu penyelenggaraan atas kehidupan manusia. Adapun dalam hal ini di dalam setiap pembangunan yang ada di Indonesia, tanah memiliki modal dasar atas suatu penyelenggaraan pembangunan di Indonesia. Mengenai hal ini, adapaun kedudukan tersebut ialah adanya suatu penguasaa, pemilikian, penggunaan dan juga adanya suatu pemanfaatan atas tanah dalam memperoleh suatu jaminan di dalam perlindungan hukum.

Maka oleh karena itu, dalam mengatur tentang kepemilikan tanah haruslah berdasarkan pada suatu konsep dasar di NKRI yang merupakan negara yang sangat memegang teguh ketentuan hukum yang berlaku, yang mana sangatlah berorientasi atas kesejahteraan umum, dimana hal ini sebagaimana dimaksud di dalam UUD Tahun 1945. Mengenai hal ini, bahwasannya di dalam membentuk suatu negara, maka Pemerintah dalam hal ini memasuki atas suatu aspek di dalam suatu kehidupan dan juga di dalam suatu penghidupan bagi masyarakat yang salah satu merupakan bagian daripada perorangan ataupun juga bagi kalangan masyarakat. ${ }^{1}$

Maka dengan demikian, warga masyarakat di dalam mempertahankan atas haknya tersebut, maka Pemerintah harus berupaya dalam menjalankan atas suatu kepentingan terhadap adanya suatu terselenggaranya atas suatu kesejahteraan umum bagi para kehidupan masyarakat. Adapun di dalam suatu kehidupan di masyarakat pada umumnya didasari pada kehidupan yang lebih harmonis, dimana harus berpedoman pada suatu kaidah dan juga standar yang dapat dipatuhi bagi setiap kalangan masyarakat.

Dengan

demikian berdasarkan pada suatu tanda adanya hak atas tanah, maka dapat diartikan bahwasannya negara menjamin penuh atas kepastian hukum atas kepemilikan tanah tersebut demi tujuannya agar terpisahkan daripada kepentingan orang lain, masyarakat dan juga negara.

Mengenai hal ini adapun yang pada dasarnya yang menjadi kenyataannya yang bahwasannya di setiap suatu permasalahan atas tanah yang berada dan muncul di kehidupan masyarakat, yang bahwasannya pertanahan ialah suatu 
objek yang dapat dimiliki oleh orang/masyarakat. Maka untuk itu adapun suatu permasalahan tanah yang kerap terjadi ialah terdapat adanya suatu isu yang muncul dari waktu ke waktu, dimana dengan adanya suatu penambhan penduduk, para elemen di dalam mengembangkan suatu pembangunan dengan tujuan untuk dapat terpenuhinya suatu kepentingan yang telah diatur.

Mengenai hal ini suatu pemasalahan di dalam pertanahan ialah menjadi suatu permaslahan yang hampir sulit untuk dipecahkan, dikarenakan ada kaitannya dengan suatu aspek di dala $m$ kehidupan yang dalam hal ini memiliki sifat yang melambangkan adanya suatu nilai-nilai kebaikan.(Nanda Sagara, Bahmid, Irda Pratiwi, 2019). ${ }^{3}$

Adapun di dalam hal ini, mengenai suatu adanya persengketaan di dalam bidang pertanahan, maka memiliki suatu kecenderunagan atas meningkatnya suatu permasalahan yang ada yang sangat mempengaruhi suatu dinamika di dalam bidang ekonomi, sosial dan juga politik.

Adapun dalam hal ini suatu pengaduan-pengaduan atas masalah pertanahan, maka yang pada dasarnya ialah salah satu bentuk fenomena yang sangat mempersoalkan atas adanya suatu kebenaran di dalam suatu kaitannya dengan adanya kekuatan hukum pada pertanahan. Dalam hal ini mengenai adanya suatu produk-produk yang

3 Nanda Sagara, Bahmid, Irda Pratiwi, Efektivitas Pendaftaran Tanah Sistematis Lengkap (Studi Di Kantor ATR/BPN Kota Tanjungbalai), (Kisaran : Universitas Asahan, 2019), hlm. 1 dikeluarkan oleh Badan Pertanahan ialah adanya suatu ketentuan seperti atas terdapatnya suatu riwayat atas perolehan tanah dan juga sebagainya, yang dimana pendek katanya hampir suatu aspek Pertanahan maka dapat berupa adanya suatu riwayat perolehan tanah, adanya penguasaan, adanya suatu pemilikan dan juga adanya adanya suatu pembebasan tanah, penggunaan tanah dan juga pemanfaatan tanah dan juga pendaftaran tanah sebagainya.

Maka untuk itu tanah harus dapat diberikan suatu pengaturannya secara khusus oleh Lembaga yang berwenang dalam hal mengurusi pertanahan. Mengenai hal ini, pada Perpres No. 10 Tahun 2006, dalam hal ini menegaskan bahwasannya dalam pembentukan BPN didsari pada penyusunan dengan cara memperhatikan suatu sisi dan juga suatu aspek atas aspirasi dan juga peran serta masyarakat guna bertujuan untuk dapat menunjang kesejahteraan umum.

Mengenai hal ini suatu permasalahan di dalam menyelesaikan suatu permasalahan yang terjadi di bidang pertanahan, maka akan diusut secara tuntas, yang dimana akan diusut dengan cara melalui penyelesaian sengketa alternatif atau mediasi.

Mengenai suatu penyelesaian lainnya apabila tidak menemukan titik terang dalam penyelesaian sengketa tersebut, maka dapat diselesaikan dengan cara melalui persidangan di Pengadilan/litigasi, dengan sesuai dengan suatu ketentuan hukum yang berlaku dan yang ada di Indonesia. Adapun di dalam suatu penyelesaian sengketa yang sering dilakukan oleh BPN 
ialah melalui meidasi karena prosesnya relatif sederhana, maka pada waktunya singkat dan juga memiliki biaya yang dapat ditekan lebih rinci.

Adapun di dalam suatu penyelesaian sengketa yaitu dilakukan dengan cara diselesaikan melalui penyelesaian permasalahan di luar pengadilan, dimana dibutuhkan pihak ketiga untuk dapat membantu dan juga mengeksplorasi atas berbagai macam alternatif dalam penyelesaian sengketa tersebut.

Maka oleh karena itu dengan adanya suatu penyelesaian sengketa yang dilakukan dengan melalui ADR untuk melakukan mediasi, maka dapat menunjukkan suatu kecenderungan di dalam masyarakat dalam memperoleh tempat.

Maka untuk itu dengan di dasari pada suatu pemahaman di dalam penyelesaian suatu upaya mediasi, maka dapat diselesaikan dengan cara memanfaatkan tugas pokok dan juga fungsi BPN untuk dapat menyelesaian suatu sengketa yang terjadi, dimana mengingat suatu penyelesaian atas suatu permasalahan yang ada dilalui dengan cara musyawarah mufakat, yang kiranya akan mendapatkan suatu manfaat yang lebih positif di dalam melakukan suatu dalam penyelesaian sengketa pertanahan.

Akan tetapi adapun dampak negatif dari penambahan suatu tanah yang dimiliki oleh para pemilik tanah yang misalkan berbatasn langsung dengan sungai tepi laut yang berlumpur namun sungai tersebut kering, maka ukuran tanah yang dimiliki jika dilakukan pengukuran pastinya berbeda dari sebelumnya.
Maka oleh karena itu dengan berdasarkan dari hasil penjelasan ataupun juga dari hasil suatu pemaparan yang telah diuraikan di dalam latar belakang diatas, dalam melakukan dan mengadakan suatu penelitian hukum dengan judul Tinjauan Yuridis Terhadap Hilangnya Hak Guna Bangunan Karena Di Telantarkan Oleh Pemiliknya Ditinjau Peraturan Kepala Badan Pertanahan Nasional Republik Indonesia Nomor 4 Tahun 2010 Tentang Tata Cara Penertiban Tanah Terlantar.

\section{METODE PENELITIAN}

Penelitain yang digunakan di dalam penelitian hukum ini ialah tipe penelitian hukum normatif, dmana dilakukan dengan cara meneliti berbagai macam penjelasa yang berasal dari tiga bahan hukum, yaitu bahan hukum primer, bahan hukum sekunder, dan juga bahan hukum tersier. (Soekanto \& Mamudji, 2011). ${ }^{4}$

Adapun mengenai penelitian hukum normatif ini digunakan berbagai macam suatu penjelasan dokrinal dan juga dikonsepkan sebagai apa yang dilakukan secara tertulis yaitu dengan berdasarkan pada Peraturan Perundang-Undangan atau sebagai salah satu kaidah yang norma yang juga merupakan sebagai suatu patokan di dalam berprilaku manusia yang dianggap sangat pantas.

Oleh sebab itu, dalam penelitian hukum normatif tersebut

4 Soerjono Soekanto dan Sri Mamudji, Penelitian Hukum Normatif Suatu Tinjauan Singkat, (Jakarta : PT. Raja Grafindo Persada, 2011), hlm. 13 
pada penelitian hukum ini, terbagi menjadi beberapa bagian, yaitu : a. Melakukan pendekatan kasus. b. Melakukan pendekatan PerundangUndangan . c. Adanya pendekatan perbandingan hokum. d. Adanya suatu pendekatan konseptual. e. Adanya pendekatan historis.

Maka oleh karena dari hasil rumusan masalah serta dari tujuan penelitian, maka tipe penelitian yang digunakan oleh peneliti dalam penelitian ini, yaitu dengan menggunakan tipe penelitian hukum normatif, dan dalam hal ini juga pendekatan yang digunakan di dalam penelitian ini yaitu pendekatan Perundang-Undangan.

$$
\text { Pendekatan Penelitian }
$$

Adapun di dalam melakukan penelitian hukum normatif ini, maka peneliti malakukan suatu pendekatan dengan cara mencari berbagai macam fenomena-fenomena yang sudah ada, baik dalam hal ini fenomena yang secara ilmiah maupun fenomena-fenomena yang berasal dari ciptaan manusia. Mengenai fenomena-fenomena tersebut, dalam hal ini dapat berupa bentuk, suatu aktivitas, karakteristik, suatu perubahan, hubungan, kesamaan, dan juga terdapat adanya suatu perbedaan antara fenomena yang satu dengan fenomena yang lainnya.

Sumber Bahan Hukum Dalam melakukan suatu penelitian yang normatif, maka dalam hal ini memakai suatu pendekatan yang tertuang di dalam PerUU, yang juga sumber bahan-bahan hukum yang sebagai bahan-bahan referensi terhadap penelitian hukum normatif ini.
Adapun peneliti dalam melakukan penelitian hukum empiris ini menggunakan 3 (tiga) cara yang dilakukan, yaitu :

Bahan Hukum Primer Adapun di dalam hal ini suatu bahan hukum yang primer ini menggunakan berbagai macam suatu bahan-bahan hukum dengan memiliki sifat dengan cara otoritatif, dan dilakukan dengan cara menggunakan hukum normatif, yang mana dijelaskan sebagai berikut : a. Peraturan Perundang-Undangan, $b$. Mengenai catatan-catatan yang secara resmi yang berasal dari Peraturan Perundang-Undangan.

Bahan Hukum Sekunder Mengenai di dalam hal ini suatu bahan hukum sekundwer yang digunakan ialah dengan cara menggunakan suatu bahan pendukung yang berasal daripada bahan hukum primer. ${ }^{5}$

Adapun di dalam suatu penelitian hukum normatif ini, maka peneliti menggunakan bahan hukum sekunder, yaitu : a. Mengenai bukubuku hukum, yang dalam hal ini termasuk ialah skripsi, tesis, dan juga disertasi hukum. b. Mengenai jurnaljurnal hukum. c. Mengenai kamuskamus hukum. d. Mengenai komentar-komentar atas putusan yang telah diputuskan oleh majelis hakim.

Bahan Hukum Tersier Mengenai di dalam hal inin suatu ketentuan yang terdapat di dalam bahan hukum tersier ialah suatu ketentuan yang digunakan dengan

\footnotetext{
${ }^{5}$ Adrian Sutedi, 2007, Implementasi Prinsip Kepentingan Umum dalam Pengadaan Tanah Untuk Pembangunan, Sinar Grafika, Jakarta, (selanjutnya disebut Adrian Sutedi I) hlm. 45.
} 
cara memakai suatu penelitian hukum normatif, dimana dengan cara menggunakan bahan-bahan non hukum yang sangat menunjang atas berbagai macam bahan hukum yang pimer dan juga bahan hukum yang sekunder, majalah, wikipedia.

Adapun pada penelitian hukum normatif ini yang telah adanya suatu berbagai macam permasalahan yang ada saat ini dengan cara dikaji secara terlebih dahulu daripada berbagai macam sumber-sumber bahan hukum yang menjadi bahan referensi yang dapat dipercaya daripada suatu hal terhadap kebenarannya dalam suatu penelitian hukum normatif ini yang diteliti oleh peneliti.

Prosedur Pengumpulan Bahan Hukum Adapun dalam hal ini tekinik pengumpulan data daripada bahan hukum yang telah digunakan di dalam penelitian hukum normatif oleh peneliti, maka untuk itu dilakukan dengan cara melakukan penelusuran di berbagai bahan-bahan hukum di Perpustakaan UNA dan juga Perpustakaan FH UNA.

Mengenai tujuan di dalam penelitian hukum ini, yaitu dengan cara mencari berbagai macam bukubuku hukum serta Peraturan Perundang-Undangan dengan cara menyesuaikan dengan judul Tinjauan Yuridis Terhadap Hilangnya Hak Guna Bangunan Karena Di Telantarkan Oleh Pemiliknya Ditinjau Peraturan Kepala Badan Pertanahan Nasional Republik Indonesia Nomor 4 Tahun 2010 Tentang Tata Cara Penertiban Tanah Terlantar.

Analisis Bahan Hukum Dalam suatu analisis bahan hukum yang digunakan di dalam penelitian hukum empiris ini, maka oleh karena itu dilakukan dengan cara menagnalisis atas semua bahan hukum dan dilakukan pemeriksaan serta pengelompokkan atas semua permasalahan yang lebih baik dan juga melakukan pengelompokkan ke dalam bagian-bagian di dalam suatu tertentu, yang dalam hal bertujuan untuk diolah menjadi suatu bahan informasi pada penelitian ini.

\section{HASIL DAN PEMBAHASAN Mekanisme Pelaksanaan Hak Bangunan (HGB) Apabila Diltelantarkan Pemilik Bangunan}

Dalam hal ini suatu tanah memiliki fungsi dan juga nilai yang sangat memadai dan juga ekonomis, dikarenakan berfungsi dalam hal untuk kepentigan pribadi atas tanah tersebut, maka demi kepentigan umum tersebut, maka tanah dalam hal ini memiliki kehidupan yang menjanjikan bagi kehidupan manusia, dan dalam hal ini pula tanah memiliki kedudukan yang sangatlah penting, sebab hampir berbagai macam aspek di dalam suatu kehidupan manusia, tanah yang sesungguhnya tidak hanya dapat keberadaan tanah yang sesungguhnya dan juga tidak hanya dapat sebagai salah satu fungsi yang menunjang ekonomi saja melainkan juga dapat berfungsi untuk segala kehidupan lainnya. Adapun dalam hal ini tanah memiliki peran yang sangat penting di dalam Negara Indonesia, sebab karena tanah merupakan bagian hal terpenting dari suatu wilayah NKRI.

"Hak Numpang Karang adalah suatu hak kebendaan untuk mempunyai gedung-gedung, bangunan-bangunan 
dan penanaman di atas pekarangan orang lain."

Sedangkan Pasal 713 Kitab Undang-Undang Hukum Perdata menentukan bahwasannya : "Perbuatan perdata yang melahirkan Hak Numpang Karang, harus diumumkan dengan nyata yang ditentukan dalam Pasal 620 UndangUndang Hukum Perdata." Berdasarkan Pasal 12 UU Nomor 56 Tahun 1960 tentang Penetapan Luas tanah pertanian maksimum luas dan jumlah tanah untuk perusahaan dan pembangunan lainnya akan diatur dengan Peraturan Pemerintah. Hapusnya Hak Guna Bangunan menurut Pasal 40 UUPA karena : 1. Jangka waktu berakhir . 2. Dihentikan sebelum jangka waktunya berakhir karena sesuatu syarat tidak dipenuhi. 3. Dilepaskan oleh pemegang haknya sebelum jangka waktunya berakhir. 4 . Ditelantarkan 5. Tanahnya musnah. 6. Ketentuan dalam Pasal 36 ayat (2)

Dari penjelasan III/3 dalam UUPA maka hak yang dipunyai oleh pemegang hak sangat terbatas oleh karena didirikan di atas tanah yang bukan haknya, jadi hanya terjadi sepanjang waktu tertentu. Tidak seperti halnya dengan hak milik yang haknya adalah terpenuh di antara hak-hak atas tanah. Setelah jangka waktunya berakhir hak guna bangunan dapat diperpanjang lagi paling lama 20 tahun atas permintaan pemegang hak dan dengan mengingat keperluan serta keadaan bangunan-bangunan.

Hal tersebut ditentukan dalam Pasal 35 ayat (2) UUPA yang menentukan bahwa : "Atas permintaan pemegang hak dan dengan mengingat atas adanya suatu keperluan serta adanya suatu keadaan terhadap bangunan, jangka waktu tersebut dalam ayat (1) dapat diperpanjang dengan waktu paling lama 20 tahun." 31

\section{Akibat Hukum Hak Guna Bangunan (HGB) Karena Diterlantarkan Pemilik Bangunan}

Dalam hal ini mengenai adanya suatu konflik di dalam aspek pertanahan, maka dalam hal ini merupakan bentuk daripada suatu keekstriman yang dalam hal ini sering terjadi, karena dalam hal ini tanah merupakan suatu objek yang sangat rentan untuk trjadi suatu permasalahan.

Adapun dalam hal ini suatu penanganan atas adanya suatu penyelesaian terhadap adanya upaya di dalam suatu penelantaran terhadap bangunan, maka dapat mengakibatkan yang mana bahwasannya yang akan dilakukan ialah dapat berupa tanah dengan didasari pada Hak Guna Bangunan (HGB) yang sudah telantar adalah tanah yang mana sebagai berikut : 1 . tidak dimanfaatkan dan atau dipelihara dengan baik; 2 . tanah yang tidak dipergunakan sesuai dengan keadaan, sifat atau tujuan dari pemberian haknya tersebut. dengan sanksi berupa tindakan: a.Penguasaan secara langsung oleh negara atas bidang tanah yang sudah dinyatakan sebagai telantar tersebut; b. Kepada bekas pemegang haknya atau pihak yang sudah memperoleh dasar penguasaan atas tanah yang kemudian dinyatakan sebagai tanah telantar tersebut diberikan ganti rugi sebesar harga perolehan yang berdasarkan bukti-bukti tertulis yang 
ada telah dibayar oleh yang bersangkutan untuk memperoleh hak atau dasar penguasaan atas tanah tersebut yang jumlahnya ditetapkan oleh menteri; c. Dalam hal pemegang hak atau pihak yang telah memperoleh dasar penguasaan atas tanah tersebut telah mengeluarkan biaya untuk membuat prasarana fisik atau bangunan di atas tanah yangdinyatakan telantar, maka jumlah yang telah dikeluarkan tersebut diperhatikan dalam penetapan ganti rugi. d. Dalam hal tanah yang telantar tersebut hendak dipergunakan oleh pihak ketiga, maka ganti rugi tersebut akan dibebankan pada pihak yang oleh menteri ditetapkan sebagai pemegang hak yang baru atas tanah tersebut.

\section{KESIMPULAN}

Dari adanya suatu penjelasan dan juga pemaparan yang telah dibahas di dalam suatu penelitian hukum ini yang diteliti oleh peneliti, maka oleh karena itu di dalam suatu pembahasan pada penelitian hukum ini. Maka dalam hal ini dapat ditarik daripada suatu kesimpulan di dalam penelitian hukum ini yaitu : 1 . Mekanisme Pelaksanaan Hak Bangunan (HGB) Apabila Diltelantarkan Pemilik Bangunan. Pemberian Hak Guna Bangunan di atas tanah Hak Milik, dapat ditemukan penjelasannya dalam Pasal 24 Peraturan Pemerintah No. 40 Tahun 1996. 2. Akibat Hukum Penambahan Tanah Berdasarkan Undang-Undang Pokok Agraria. Dalam hal ini mengenai adanya suatu konflik di dalam aspek pertanahan, maka dalam hal ini merupakan bentuk daripada suatu keekstriman yang dalam hal ini sering terjadi, karena dalam hal ini tanah merupakan suatu objek yang sangat rentan untuk trjadi suatu permasalahan.

Berdasarkan daripada hasil yang dijelaskan dalam kesimpulan pada penelitian hukum ini secara lebih jelas yang dipaparkan diatas, maka untuk itu dalam hal ini peneliti dalam melakukan penelitian hukum ini menyampaikan adanya suatu saran terkait di dalam penelitian hukum ini, yang dalam hal ini meliputi : 1. Sebaiknya mekanisme pelaksanaan hak bangunan (HGB) apabila diltelantarkan pemilik bangunan, maka harus melalui prosedur yang telah ditetapkan. 2 . Sebaiknya pemilik bangunan dapat lebih memperhatikan dan juga merawat bangunan yang mereka punya agar tidak menimbulkan akibat hukum Hak Guna Bangunan (HGB) karena diterlantarkan pemilik bangunan.

\section{DAFTAR PUSTAKA \\ Buku}

Bahmid, (2016). Penetapan bea perolehan hak atas tanah dan bangunan dalam peralihan hak atas tanah di kabupaten asahan. I, 1-28.

Nanda Sagara, Bahmid, I. Pratiwi (2019).

Efektivitas pendaftaran tanah sistematis lengkap (studi di kantor atr/bpn kota tanjungbalai). 1(1), 57-60.

Soekanto, S., \& Mamudji, S. (2011). Penelitian Hukum Normatif, Suatu Tinjauan Singkat. In Jakarta: Raja Grafindo Persada.

Togie Halomoan Gultom, 
Bahmid, I. Pratiwi. (2019).

Peran Lurah Dalam Ganti

Rugi Tanah Dikelurahan

Keramat Kubah Kota

Tanjungbalai. Jurnal Pionir

LPPM Universitas Asahan,

$5,127-134$. 